PRZEGLĄD NAUK HISTORYCZNYCH 2016, R. XV, NR 1

http://dx.doi.org/10.18778/1644-857X.15.01.05

KRZYSZTOF LESIAKOWSKI

(UNIWERSYTET ŁÓDZKI)*

\title{
Kadra Centralnej Szkoły Ministerstwa Bezpieczeństwa Publicznego 1945-1947 Początki polskiego aparatu bezpieczeństwa
}

Streszczenie. Aparat bezpieczeństwa był bardzo ważnym narzędziem, które komuniści wykorzystywali w walce o władzę po II wojnie światowej. Tysiące funkcjonariuszy potrzebowało jednak stosownego przeszkolenia. W latach 1945-1947 byli oni szkoleni w Centralnej Szkole Ministerstwa Bezpieczeństwa Publicznego w Łodzi. Wykładowcami w niej byli przedwojenni polscy komuniści i tzw. kujbyszewiacy - absolwenci kursu NKWD (Ludowy Komisariat Spraw Wewnętrznych), zorganizowanego w kwietniu-lipcu 1944 r. w sowieckim mieście Kujbyszew nad rzeka Wołgą. Personel ten cechował młody wiek i brak doświadczenia zawodowego. Dlatego jego przydatność w kształceniu funkcjonariuszy aparatu bezpieczeństwa w powojennej Polsce była skromna.

Slowa kluczowe: aparat bezpieczeństwa w Polsce, Ministerstwo Bezpieczeństwa Publicznego, ośrodki szkolenia funkcjonariuszy, Centralna Szkoła Ministerstwa Bezpieczeństwa Publicznego 1945-1947.

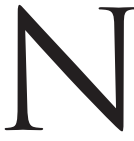

ad dziejami Polski po II wojnie światowej mocno zaciążyła działalność aparatu bezpieczeństwa. Był on niezwykle ważnym narzędziem wykorzystywanym przez komunistów i ich sojuszników w walce o zdobycie i utrzymanie władzy politycznej. Stąd tematyka ta jest przedmiotem rozległych badań historycznych ${ }^{1}$.

* Wydział Filozoficzno-Historyczny, Instytut Historii, Katedra Historii Polski i Świata po 1945 roku.

${ }^{1}$ Literatura na ten temat jest bardzo obszerna. $Z$ najnowszych publikacji należy wymienić m.in. Archiwalia komunistycznego aparatu represji: zagadnienia źródłoznawcze, red. F. Musiał, Kraków 2012; R. Ciupa, M. Komaniecka, Szpiegowski arsenał bezpieki: obserwacja, technika operacyjna, kontrola korespondencji 
Analizowane są struktury bezpieki i ich działalność, a także kwestie personalne. Trudno jednak zrozumieć funkcjonowanie aparatu bezpieczeństwa bez refleksji dotyczącej kwestii szkolenia funkcjonariuszy. Sprawa nie była szczególnie skomplikowana w okresie, gdy aparat już okrzepł i stworzył własne ośrodki szkoleniowe. Jednak pytanie: jak to wyglądało na początku, ciagle jest intrygujace. Liczne zastępy funkcjonariuszy $z$ chwila podjęcia służby - w $1945 \mathrm{r}$. było to już blisko 27 tys. - musiały przecież być przeszkolone, choćby w bardzo ograniczonym zakresie. Zatem gdzie i kto ich szkolił?

Przedmiotem poniższego tekstu będzie poszukiwanie odpowiedzi na powyższe pytanie ze szczególnym uwzględnieniem jego drugiego segmentu - tzn. kim były osoby, które stanowiły trzon kadry istniejącej w latach 1945-1947 Centralnej Szkoły (CS) Ministerstwa Bezpieczeństwa Publicznego (MBP). Problem ten jest ciekawy $z$ uwagi na to, że $z$ oczywistych względów nowa władza nie mogła skorzystać $z$ przedwojennych kadr policyjnych czy kontrwywiadu wojskowego, które zajmowały się zwalczaniem nielegalnych organizacji politycznych. Czy zatem wykładowcami byli - jakby należało przypuszczać - wyłącznie oficerowie sowieckich służb specjalnych, a może osoby polskiego pochodzenia wcześniej odpowiednio przygotowane do roli „pierwszych nauczycieli” tworzonej bezpieki? W tym drugim wypadku chodzi głównie o tzw. kujbyszewiaków, czyli absolwentów szkolenia zorganizowanego w kwietniu-lipcu 1944 r. w Kujbyszewie w Związu Socjalistycznych Republik Radzieckich (ZSRR) ${ }^{2}$.

\section{Powstanie CS MBP}

CS MBP powstała na bazie utworzonej 17 października 1944 r. w Lublinie Szkoły Oficerów Bezpieczeństwa przy Resorcie Bezpieczeństwa Publicznego. W związku $z$ rozpoczęciem w styczniu następnego roku wielkiej ofensywy przez wojska sowieckie zapadła decyzja o przeniesieniu placówki do Łodzi ${ }^{3}$. Wynikało ono $z$ tego, że

jako środki pracy Służby Bezpieczeństwa PRL, Katowice 2011; Historyczno-prawna analiza struktur organów bezpieczeństwa Polski Ludowej (1944-1990): zbiór studiów, red. A. Jusupović, R. Leśkiewicz, Warszawa 2013; R. Terlecki, Miecz i tarcza komunizmu: historia aparatu bezpieczeństwa w Polsce 1944-1990, Kraków 2013; Wokół teczek bezpieki: zagadnienia metodologiczno-źródłoznawcze, red. F. Musiał, Kraków 2006; „Zwyczajny resort”. Studia o aparacie bezpieczeństwa 1944-1956, red. K. Krajewski, T. Łabuszewski, Warszawa 2005.

2 M. Korkuć, „Kujbyszewiacy” - awangarda UB, „Arcana” 2002, z. 46-47, s. 74-95.

3 Wyższa Szkoła Oficerska MSW im. F. Dzierżyńskiego. Rodowód, powstanie idziałalność, Warszawa 1983, s. 10. Por. też A. F rą cze k, Wspomnienia absolwenta, 
w zniszczonej stolicy nie było odpowiednich warunków lokalowych. Warto wspomnieć, że na takie rozwiązanie na okres przejściowy zdecydowało się wiele instytucji kulturalnych, prasowo-wydawniczych i gospodarczych. Podobnie było $z$ niektórymi szkołami, w tym $z$ tymi o charakterze specjalnym. W 1945 r. w Łodzi zaczęły też działać: Szkoła Oficerów Polityczno-Wychowawczych Wojska Polskiego (WP), Szkoła Oficerska Intendentury WP; Szkoła Oficerów Liniowych Milicji Obywatelskiej (MO) - Kurs Przeszkolenia Kierowników Jednostek (później Ośrodek Szkolenia Oficerów MO), Centralna Szkoła Oficerów Polityczno-Wychowawczych MO oraz Centralna Szkoła Partyjna i Centralna Szkoła Zwiazku Walki Młodych, a w podłódzkim Andrzejowie od kwietnia 1945 r. zaczęło działać Centrum Wyszkolenia Wojsk Wewnętrznych (później Oficerska Szkoła Korpusu Bezpieczeństwa Wewnętrznego $)^{4}$. W tej sytuacji zmiana lokalizacji Szkoły Oficerów Bezpieczeństwa nie było niczym wyjątkowym. $\mathrm{Z}$ chwila przeniesienia - dokładniej 5 marca 1945 r. - została zmieniona jej nazwa na Centralną Szkołę MBP5 , co było zbieżne - jak wynika $z$ nazw wymienionych placówek $-z$ ówcześnie stosowana terminologia. Zmieniono także jej zwierzchnika (dyrektora), którym w miejsce dotychczasowego kpt./mjr. Leona Ajzena (Lajb Wolf Ajzen, znany jako Leon Andrzejewski) ${ }^{6}$ został mjr Mieczysław Broniatowski ${ }^{7}$. Ten ostatni tak opisał ten moment w swoich wspomnieniach: „Leczyłem się prawie miesiąc. Po wyzdrowieniu [chorował

[w:] Legionowski ośrodek szkolenia Służby Bezpieczeństwa, cz. 1 (KujbyszewLublin-Łódź), Legionowo 1989, s. 27-30.

4 Ochrona bezpieczeństwa państwa i porzadku publicznego w Polsce 1944-1988, red. T. Walichnowski, Warszawa 1989, s. 77; W służbie ludowej ojczyzny $i$ społeczeństwa. W obronie ładu i porządku społecznego, red. Z. Jakubowski, Łódź 1986, s. 77; M. J aw or ski, Korpus Bezpieczeństwa Wewnętrznego 1945-1965, Warszawa 1984, s. 34; Kształtowanie władzy ludowej $w$ Łodzi $i$ województwie Łódzkim w 1945 roku. Wybór źródeł, oprac. G. Adamczewska, M. Bandurka, E. Chobot, Warszawa-Łódź 1985, s. 89-90.

5 A. Ko chański, Polska 1944-1991. Informator historyczny, t. I (Podział administracyjny. Ważniejsze akty prawne, decyzje i enuncjacje państwowe [1944-1956]), Warszawa 1996, s. 38.

${ }^{6}$ Był zastępca do spraw polityczno-wychowawczych i wykładowca historii ruchu robotniczego na kursie specjalnym Ludowego Komisariatu Spraw Wewnętrznych (NKWD) w Kujbyszewie, równolegle $z$ kierowaniem Szkołą w Lublinie od października 1944 r. do czerwca 1946 r. pełnił funkcję zastępcy szefa Biura Personalnego MBP (Wybór wydarzeń $z$ dziejów walk $w$ obronie władzy ludowej $w$ Polsce $w$ latach 1944-1952, red. T. Walichnowski, Warszawa 1985, s. 30; J. Ślęczka, Rodowód Wyższej Szkoły Oficerskiej im. F. Dzierżyńskiego, Warszawa 1989, s. 13, 18).

7 Wybór wydarzeń z dziejów..., s. 39. 
na gruźlicę - przyp. K.L.] zgłosiłem się do ministra Stanisława Radkiewicza do raportu $z$ prośba o umożliwienie mi kontynuowania studiów medycznych, przerwanych w 1936 r., lub o skierowanie na akademię wojskową. Odmówił, oświadczając, że jeśli tak palę się do studiów, to ma dla mnie propozycję - stanowisko dyrektora Centralnej Szkoły MBP w Łodzi. No cóż, zgodziłem się i rozkazem z 5 marca 1945 r. zostałem mianowany na to stanowisko"8.

CS MBP została powołana rozkazem $\mathrm{nr} 8$ ministra S. Radkiewicza z 15 marca 1945 r. Zarządził on otwarcie szkoły na 20 marca. W jej murach przy ul. Staszica 1/3 i Głowackiego 10/12 miało się szkolić 450-500 osób, podzielonych na trzy równoległe kursy, po 150-175 osób każdy. Czas trwania kursu minister określił na dwa miesiące ${ }^{9}$. Ponieważ zajęto dawny budynek szkolny i internat, możliwości prowadzenia działalności szkoleniowej należy ocenić jako dobre. Budynek wymagał jednak przystosowania. Ponadto brakowało $\mathrm{w}$ nim niezbędnych urządzeń do zorganizowania szkolenia o charakterze specjalnym. Inna kwestia były początkowe perturbacje $z$ zapewnieniem kursantom wyżywienia i umundurowania ${ }^{10}$.

\section{Etaty kadrowe}

Według rozkazu etatowego z 21 czerwca 1945 r. struktura organizacyjna CS MBP przedstawiała się następująco:

- Dowództwo: dowódca szkoły, zastępca dowódcy ds. polityczno-wychowawczych, zastępca dowódcy ds. wyszkolenia, czterech dowódców kompanii, czterech zastępców dowódcy kompanii;

- Wydział Szkoleniowy: kierownik, ośmiu wykładowców przedmiotów specjalnych, czterech wykładowców nauk polityczno-historycznych, trzech wykładowców języka polskiego;

- Wydział Finansowo-Gospodarczy (później Wydział Administracyjno-Gospodarczy) - kierownik, zastępca kierownika i 16 pracowników technicznych;

${ }^{8}$ M. Broniatowski, Organizacja wojewódzkich urzędów bezpieczeństwa publicznego w Rzeszowie $i$ Warszawie (sierpień 1944 - styczeń 1945), „Zeszyty Historyczne Akademii Spraw Wewnętrznych" 1986, t. VI, s. 196.

${ }^{9}$ Rozkaz nr 8, 15 III 1945 r., Archiwum Instytutu Pamięci Narodowej w Warszawie [dalej: AIPN Wa], 1572/257, k. 17.

10 Sprawozdanie $z$ rocznej pracy CS MBP wygłoszone dnia 31 III 1946 r. na uroczystości Szkoły przez ppłk. Broniatowskiego, 8 IV 1945 r., AIPN Wa, 1572/234, k. 13; Sprawozdanie z rocznej pracy CS MBP, wygłoszone dnia 31 III 1946 r. na uroczystości Szkoły przez kpt. Bierzwińskiego, 8 IV 1946 r., ibidem, k. 8. 
- ambulatorium (troje pracowników), stołówka (28 osób), komendantura (21 osób) ${ }^{11}$.

W wymienionych komórkach przewidziano łacznie 117 etatów, $z$ tego 34 oficerskie, jeden podoficerski, 12 dla szeregowych i 70 dla osób cywilnych ${ }^{12}$. Ogółem w połowie 1945 r. CS zatrudniała 109 osób, do obsadzenia pozostały jedno stanowisko oficerskie i siedem cywilnych ${ }^{13}$. Można więc stwierdzić, że stan kadrowy CS nie przedstawiał się źle. Warto dodać, że WAG miał dodatkowo do dyspozycji liczaca 30 osób grupę jeńców niemieckich ${ }^{14}$, których wykorzystywano - jak należy sądzić - do prac o charakterze porządkowym i gospodarczym.

Już 3 sierpnia 1945 r. minister wydał nowy rozkaz etatowy dla szkoły, co należy wiązać ze spodziewanym rozszerzeniem szkolenia. Łącznie pracowników i słuchaczy w CS MBP miało być 970 osób, $z$ tego 170 to kadra i 800 słuchaczy $^{15}$. Jeśli chodzi o kadrę, to miało ją tworzyć 51 oficerów, dwóch podoficerów, 15 szeregowych, 102 pracowników cywilnych. Zaszły też pewne zmiany w liczebności poszczególnych komórek organizacyjnych. W Dowództwie (później nazwanym Kierownictwem) pojawiło się dodatkowo dwóch dowódców batalionów, a liczba dowódców i zastępców dowódców kompanii wzrosła do sześciu. W Wydziale Szkoleniowym zwiększono liczbę wykładowców do 24 (14 przedmiotów specjalnych, siedmiu nauk polityczno-historycznych, trzech przedmiotów ogólnych), pojawiło się też pięciu tzw. brygadierów seminaryjnych (inaczej asystentów wykładowców $)^{16}$. Również w innych komórkach przewidziano większą liczbę etatów.

Po roku istnienia szkoły w Łodzi, w dniu 25 marca 1946 r., minister S. Radkiewicz wydał dla tej placówki kolejny rozkaz etatowy. Nie wprowadzał on specjalnych zmian w strukturze organizacyjnej szkoły. Od marca 1946 r. w CS miały być 82 stanowiska, w tym 53 oficerskie, dwa podoficerskie, 12 dla szeregowych i 15 cywilnych. Do tego 32 pracowników kontraktowych. Łacznie dawało to

11 Etat nr P8/2, 21 VI 1945, AIPN Wa, MBP, 2279, k. 3-5.

12 Ibidem, k. 3.

13 Ibidem, k. 4-5.

${ }^{14}$ L. Skwa rczek, Wspomnienia z łódzkiego okresu Centralnej Szkoły Ministerstwa Bezpieczeństwa Publicznego, [w:] Legionowski ośrodek szkolenia..., s. 34.

${ }^{15} \mathrm{~W}$ treści rozkazu występuje błąd rachunkowy, którego skutkiem jest liczba 969 kadry i kursantów (Etat nr P8/2, 3 VIII 1945 r., AIPN Wa, MBP, 2279, k. 1).

${ }^{16}$ Etat nr P8/2, 3 VIII 1945 r., AIPN Wa, MBP, 2279, k. 1-2. 
114 etatów $^{17}$. Oznacza to, że poważnie zmniejszono stan pracowników cywilnych, których usiłowano zastąpić dużo mniejszą liczba pracowników kontraktowych. Choć kolejne korekty zwiększały ogólną liczbę pracowników, w tym zwłaszcza pracowników kontraktowych ${ }^{18}$, to jednak od drugiej połowy 1946 r. liczba pracowników szkoły, zwłaszcza obsługi, zaczęła maleć w stosunku do podobnego okresu roku poprzedniego. Wiązać to należy z zarysowaniem się w tym czasie perspektywy przeniesienia tej placówki do Warszawy, co potencjalnie było łatwiejsze do przeprowadzenia $z$ mniejszą liczba etatowych pracowników cywilnych, nie mówiąc o kontraktowych.

W praktycznej działalności CS MBP cierpiała na niedostatek odpowiedniej kadry, tak w znaczeniu liczbowym, jak i fachowym. Oczywiście w pierwszym okresie jej trzon musieli stanowić pracownicy Szkoły Oficerskiej Bezpieczeństwa Publicznego z Lublina. Według stanu z 27 lutego 1945 r. na jej etatach znajdowało się 35 pracowników, którzy byli przewidziani do pracy w marcu. Podstawę stanowili: por. Tadeusz Bierzwiński - zastępca dowódcy, Emil Merz - zastępca dowódcy, ppor. Antoni Tomnicki - wykładowca, ppor. Józef Kowalski - wykładowca, Kazimierz Białek - wykładowca, Szałochow (brak imienia) - wykładowca, Władysław Bożyczko, por. Antonina Naumowa - lekarz szkoły, Benedykt Korczewski - zastępca kierownika $\mathrm{WAG}^{19}$. Resztę personelu stanowili pracownicy obsługi. Przeniesienie szkoły do Łodzi musiało być dużym problemem zwłaszcza dla osób cywilnych, stąd bardzo wielu dotychczasowych pracowników tej kategorii nie znalazło się w nowym składzie kadry CS MBP. Dla niektórych bardziej atrakcyjna była praca $\mathrm{w}$ instytucjach podległych centrali ministerstwa. Wattpić jednak należy, że do Łodzi przeszły z Lublina tylko trzy osoby - o czym wspominano w starszej literaturze przedmiotu ${ }^{20}$. Nie zmienia to jednak postaci rzeczy, że odpowiednio przygotowanych wykładowców w nowym miejscu brakowało.

Szczególnie dotkliwy był ten problem w pierwszym okresie funkcjonowania CS. Dużo kłopotu kierownictwu szkoły na gruncie łódzkim sprawiało nawet pozyskanie wykładowców od zagadnień politycznych i historycznych, przewidzianych w programie szkolenia.

${ }^{17}$ Etat nr M/19/538 Centralnej Szkoły MBP, 25 III 1946 r., AIPN Wa, MBP, 2279, k. 6-7.

18 Rozkaz 10 [12 VI 1946 r.], AIPN Wa, MBP, 2279, k. 8-9.

19 Lista pracowników Szkoły Oficerskiej B[ezpieczeństwa] P[ublicznego] na miesiąc marzec 1945 r., 27 II 1945 r., AIPN Wa, MBP, 2133, k. [21].

${ }^{20}$ Wyższa Szkoła Oficerska MSW im. F. Dzierżyńskiego..., s. 11. 
Czołowi polityczni agitatorzy tej epoki, jak Jerzy Borejsza ${ }^{21}$ czy Roman Werfel, w ogóle nie chcieli się pojawić na wykładach, mimo zaproszenia. O obsadzie zajęć decydował więc przypadek - obecność danej osoby w Łodzi ${ }^{22}$. W celu wypełnienia wykładów sięgano głównie po specjalistów $z$ prawa karnego i kryminologii, gdyż akurat byli oni stosunkowo łatwo dostępni $z$ uwagi na tworzenie się w Łodzi uniwersytetu, który angażował pracowników na Wydział Prawa. Jednak profesjonalne prelekcje prawników wykraczały poza potrzeby słuchaczy, a pewnie i ich możliwości percepcji. Niepewna była też sytuacja $z$ wykładowcami przedmiotów tzw. fachowych - byli oni dopiero pozyskiwani $z$ terenu, tzn. $z$ urzędów bezpieczeństw, ale ich słabością obok niewielkiego doświadczenia operacyjnego był całkowity brak przygotowania pedagogicznego. Sytuacja kadrowa stopniowo jednak się poprawiła, bo w Łodzi zaczęła funkcjonować Szkoła Oficerów Polityczno-Wychowawczych MO, skąd można było pozyskać wykładowców przedmiotów politycznych. Udało się także zaangażować kilku wykładowców do przedmiotów specjalnych (wyłącznie „kujbyszewiaków”23) oraz wybijających się kursantów. Tych ostatnich oczywiście należało odpowiednio uprofilować politycznie, za co odpowiadały Bronisława Merz i Barbara Giller z komórki Polskiej Partii Robotniczej (PPR) ${ }^{24}$.

W obliczu płynności kadry CS i słabości merytorycznej większości już zaangażowanych pracowników bardzo istotne było zainicjowanie akcji podnoszenia kwalifikacji zawodowych i poziomu wiedzy ogólnej oraz politycznej kadry. Problem faktycznie był bardzo poważny, jeśli weźmie się pod uwagę okoliczność, że ludzie, którzy w zdecydowanej większości dotąd nie uczyli, a co ważniejsze - rzadko legitymowali się wykształceniem wyższym niż ukończenie szkoły powszechnej, niespodziewanie stali się nauczycielami: „Nie wolno nam zapomnieć, że nie jesteśmy wykwalifikowanymi pracownikami,

${ }^{21}$ Na ten temat milczy biograf J. Borejszy. Por. E. Kra su cki, Międzynarodowy komunista. Jerzy Borejsza - biografia polityczna, Warszawa 2009.

${ }^{22}$ Wykorzystywano zapewne wykładowców $z$ istniejącej w Łodzi Centralnej Szkoły Partyjnej PPR (B. Cichocki, K. Jóźwiak, Najważniejsze sa kadry. Centralna Szkoła Partyjna PPR/ PZPR, Warszawa 2006, s. 29).

${ }^{23}$ Do końca 1945 r. zaangażowano jako wykładowców przedmiotów specjalnych łącznie dziewięciu „kujbyszewiaków”. Por. J. Ślęczka, Powstanie, rozwój organizacyjny i działalność Szkoły Oficerów Bezpieczeństwa i Centralnej Szkoły MBP (1944-1947), AIPN Wa, 1510/52, k. 44-45 [praca magisterska].

24 Sprawozdanie za okres od 20 IV-3 VI 1945 r. CS MBP, 8 VI 1945 r., AIPN Wa, 1572/234, k. 1; Sprawozdanie z pracy Szkoły Ministerstwa Bezpieczeństwa Publicznego $z$ okres 3 lat od grudnia 1944 do grudnia 1947 r., 9 XI 1947 r., ibidem, k. 28. 
żeby umieć uczyć, musimy się sami uczyć”25. Stąd konieczne było doszkalanie kadry, zwłaszcza w zakresie metodyki pedagogicznej w formie odpraw szkoleniowych, wzorcowych lekcji czy instruktaży. Celem tego procesu było ukształtowanie merytorycznie przydatnego, stabilnego i jednocześnie mocno związanego $z$ nowym porządkiem ustrojowym zespołu pracowników. „Muszę $z$ satysfakcją powiedzieć - zauważył w marcu 1946 r. kpt. T. Bierzwiński - że ludzie ci zrośli się z nami, weszli w krew, dzięki właśnie tej atmosferze, dzięki ludzkim, wzajemnym stosunkom. Więzi zadzierzgnięte będą rękojmią, że służyć będa zawsze i wszędzie Nowej Polsce"26. Potwierdzeniem tego oddania miały być ofiary śmiertelne tak spośród kursantów, jak i kadry, np. Henryka Gutowskiego, poniesione w walce $z$ antykomunistycznym podziemiem ${ }^{27}$. Ważną rolę $\mathrm{w}$ dziedzinie kształtowania oblicza politycznego kadry, ale i słuchaczy szkoły miała do odegrania wspomniana wcześniej komórka PPR. Jako dowód aktywności pracowników CS na niwie partyjnej eksponowano fakt wybrania zastępcy dowódcy placówki kpt. T. Bierzwińskiego delegatem na I Zjazd PPR w grudniu 1945 r. $^{28}$

W sytuacji dość pośpiesznego naboru pracowników nieuniknione jednak było zatrudnianie osób całkowicie przypadkowych lub niepożądanych $z$ powodów politycznych. Świadczy o tym np. sprawa Henryka Zamorskiego, zatrudnionego w CS w Łodzi w 1945 r. W przypadku tego pracownika problemem była przynależność jego żony do Armii Krajowej w czasie ostatniej wojny. W późniejszym okresie tej kobiecie dodatkowo przypisano niewłaściwy stosunek do ustroju w Polsce, do ZSRR, a także antysemityzm. Natomiast H. Zamorskiemu zarzucono, że nie wpływał należycie na swoją małżonkę „celem zmiany stosunku do obecnej rzeczywistości"29.

${ }^{25}$ Sprawozdanie z rocznej pracy CS MBP, wygłoszone dnia 31 III 1946 r. na uroczystości Szkoły przez ppłk. Broniatowskiego, 8 IV 1946 r., AIPN Wa, 1572/234, k. 1; Sprawozdanie $z$ pracy Szkoły Ministerstwa Bezpieczeństwa Publicznego z okres 3 lat od grudnia 1944 do grudnia 1947 r., 9 XI 1947 r., ibidem, k. 28.

${ }^{26}$ Sprawozdanie $z$ rocznej pracy CS MBP, wygłoszone dnia 31 III $1946 \mathrm{r}$. na uroczystości Szkoły przez kpt. Bierzwińskiego, 8 IV 1946 r., AIPN Wa, 1572/234, k. 11 .

${ }^{27}$ Brakuje danych o okolicznościach śmierci H. Gutowskiego. Nie był też wymieniany w peerelowskiej literaturze przedmiotu. Por. Polegli w walce o władzę ludowa. Materiały i zestawienia statystyczne, oprac. B. Brzeziński, L. Chrzanowski, Warszawa 1970.

${ }^{28}$ W służbie ludowej ojczyzny..., s. 46.

${ }^{29}$ Protokół nr 13 zebrania Koła PPR przy Wydziale Szkoleniowym C[entrum] W[yszkolenia] MBP w Legionowie, 3 XII 1948 r., AIPN Wa, MBP, 2739, k. 78v. 
Obciążające było także to, że małżonkowie ci mieli służąca, którą niewłaściwie traktowali (spała na strychu i nie otrzymywała stałego wynagrodzenia).

\section{Kadra kierownicza}

Mimo rozmaitych problemów z czasem wykrystalizował się podstawowy zrąb kadrowy łódzkiej CS. W marcu 1946 r. zespołowi 46 merytorycznych pracowników, z ppłk. Mieczysławem Broniatowskim jako dowódca (od 23 marca 1946 r. dyrektorem) na czele, ton nadawali: kpt. Tadeusz Bierzwiński - zastępca dowódcy szkoły, por. Emil Merz - kierownik Wydziału Szkoleniowego, por. Wiktor Łoj - naczelnik Wydziału Szkolenia (do lutego 1946 r. wykładowca), ppor. Benedykt Korczewski - kierownik Wydziału Finansowo-Gospodarczego, por. A. Naumowa - lekarz, kpt. Antoni Tomnicki - starszy wykładowca dyscyplin specjalnych, por. Konstanty Jankowski - dowódca batalionu i wykładowca, por. Józef Łobatiuk - wykładowca dyscyplin specjalnych, por. Paweł Gobiecki - wykładowca dyscyplin specjalnych, por. Wiktor Kamieniecki - wykładowca dyscyplin specjalnych, por. Ignacy Szarnas - wykładowca dyscyplin specjalnych, por. Stanisław Sawicki - dowódca kompanii, Karol Pietrasiak - wykładowca przedmiotów polityczno-historycznych, chor. Kazimierz Białek ${ }^{30}$ - wykładowca przedmiotów polityczno-historycznych, ppor. Józef Denys $^{31}$ - oficer żywnościowy, chor. Leon Sohn-Krotkiewicz, Stanisława Jasitczak - referent personalny, Krystyna Fryd - sekretarka dowództwa ${ }^{32}$. W połowie 1946 r. kadra szkoły uległa osłabieniu,

${ }^{30}$ Urodzony w 1922 r., słuchacz CS MBP od stycznia 1945 r., już w lutym tego roku wykładowca języka polskiego (miał ukończone konspiracyjnie liceum), od lutego 1946 r. p.o. dowódcy kompanii, następnie dowódca kompanii. W lipcu 1946 r. usunięty ze szkoły „jako człowiek bardzo nerwowy, nie lubiany na szkole przez słuchaczy, jak również przez d[owód]ców” i przekazany do dyspozycji szefa Wojewódzkiego Urzędu Bezpieczeństwa Publicznego (WUBP) w Krakowie (Charakterystyka, 18 VIII 1946 r., AIPN Wa, 0218/2045, k. 14v).

${ }^{31}$ Urodzony w 1923 r., łodzianin. W 1942 r. w ramach hitlerowskiej organizacji Todt pracował na terytorium Jugosławii. Po ucieczce był w partyzantce Josipa Broza Tito, w 1944 r. wrócił do Polski, najpierw przeszedł przeszkolenie w Szkole Oficerów Polityczno-Wychowawczych WP, a w styczniu-lutym 1945 r. został skierowany na kurs w Szkole Oficerów MBP w Lublinie (Zeszyt ewidencyjny, brak daty, AIPN Łd, 748/61/18, k. 1, 4, 7). Z uwagi na przeszłość z okresu wojny w 1951 r., jako niepewny politycznie, zwolniony ze służby w aparacie bezpieczeństwa.

${ }^{32}$ Do wiceministra Bezpieczeństwa Publicznego płk. Mietkowskiego, 4 III 1945 r., AIPN Wa, 1572/234, k. 8. 
zwłaszcza w odniesieniu do grupy wykładowców przedmiotów specjalnych. Nie udało się tego problemu zminimalizować dorywczym angażowaniem pracowników $z$ centrali MBP.

Warto w tym miejscu zadać sobie pytanie: kim byli i skąd przybywali czołowi pracownicy CS MBP w Łodzi? O mjr./ppłk. Mieczysławie Broniatowskim (ur. w 1912 r. w Częstochowie) wiadomo, że wywodził się $z$ żydowskiej rodziny lekarskiej. Jako student medycyny na Uniwersytecie Jagiellońskim związał się z Komunistycznym Związkiem Młodzieży Polskiej, w 1935 r. był aresztowany. W 1936 r. wyjechał przez Francję do ogarniętej wojna domowa Hiszpanii i walczył w XIII brygadzie międzynarodowej w batalionie im. Czapajewa. Po wojnie internowany przez władze francuskie we Francji, później w Algierii. W 1943 r. z pomoca sowieckiego konsula przedostał się do Związku Sowieckiego i wstąpił w szeregi 1. Dywizji Piechoty im. Kościuszki. Następnie był szefem Wydziału Personalnego Zarzadu Polityczno-Wychowawczego I Armii WP i członkiem Centralnego Biura Komunistów Polskich. W sierpniu 1944 r. organizował WUBP w Rzeszowie, a od października tego roku na województwo warszawskie, poczatkowo $z$ siedziba w Otwocku ${ }^{33}$. Dnia 31 marca 1945 r. złożył ślubowanie w CS MBP, że na powierzonym mu stanowisku będzie działał „ze wszystkich sił do ugruntowania wolności, niepodległości i potęgi demokratycznego państwa polskiego"34.

Tak wspominał pierwszy wygłoszony przez niego wykład jeden z kursantów: „Po zameldowaniu przez Rysia [tzw. Ryszarda Mierzejewskiego, jednego $z$ wykładowców Szkoły - przyp. K.L.] gotowości Szkoły do wykładu, Komendant rozłożył papiery na katedrze i rozejrzał się bystrym okiem po sali. Był w stroju galowym i brakowało mu tylko szabli, aby mógł uchodzić za sanacyjnego oficera na paradzie. [...] komendant Szkoły nie należał do krasomówców, zacinał się, nie kończył rozpoczętej myśli, mówił sucho ale nie czytał wykładu $z$ kartki, a brak odpowiedniego słowa nadrabiał gestykulacja" 35 . Z czasem ppłk. M. Broniatowski był krytykowany za opóźnianie przeniesienia CS do Warszawy z uwagi na to, że w Łodzi

${ }^{33}$ Por. M. Broniatow ski, op. cit., s. 181-182; AIPN Wa, 0194/1763, Życiorys, 30 XI 1950 r., k. 3.

${ }^{34}$ Aparat bezpieczeństwa $w$ Polsce. Kadra kierownicza, t. I (1944-1956), red. K. Szwagrzyk, Warszawa 2005, s. 62, 426; Ślubowanie, 31 III 1945 r., AIPN Wa, 0194/1763, k. 15.

${ }^{35}$ A. Bakala rc zy k, Zapiski kursanta Centralnej Szkoły MBP w Łodzi, [w:] Legionowski ośrodek szkolenia..., s. 94. 
miał rzekomo aż ośmiopokojowe mieszkanie ${ }^{36}$ - taki zarzut stawiał wiceminister Mieczysław Mietkowski - a także to, że „niezbyt przejmował się praca w Szkole". Ten drugi zarzut mógł się brać $z$ tego, że chciał studiować na Uniwersytecie Łódzkim, na Wydziale Prawno-Ekonomicznym ${ }^{37}$.

Zastępca dyrektora szkoły był Tadeusz (właściwie Dawid) Bierzwiński, ur. w 1906 r. w drobnomieszczańskiej żydowskiej rodzinie w Kaliszu. Uczył się w miejscowym gimnazjum. W młodości otarł się o ruch syjonistyczny, czego skutkiem był wyjazd w 1924 r. do Palestyny, po trzech latach wrócił do Polski i stopniowo włączył się w działalność komunistyczna. Dwukrotnie więziony, od 1935 r. odsiadywał w Sieradzu siedmioletni wyrok. W latach 1939-1941 by1 w zajętym przez sowietów Lwowie, w 1941 r. został wcielony do Armii Czerwonej, później skierowany do polskiej 3. Brygady Artylerii Haubic. W lipcu 1944 r. kontuzjowany, po czym odesłany do aparatu bezpieczeństwa ${ }^{38}$. $Z$ dniem 5 grudnia 1944 r. mianowany na stanowisko zastępcy komendanta do spraw politycznych Szkoły Oficerów Bezpieczeństwa w Lublinie. Tę samą funkcję sprawował w Lodzi.

Mimo wysokiego stanowiska i stopnia oficerskiego por./kpt. T. Bierzwiński szybko dał się poznać jako osoba o niskich walorach dowódczych, a przede wszystkim osobistych. Wykazał się skłonnością do nadużyć natury materialnej, a przede wszystkim do nawiązywania nader bliskich kontaktów z różnymi kobietami, w tym kursantkami czy spośród podległego mu personelu. „Seksualne stosunki mjr. [T. Bierzwińskiego - przyp. K.L.] z kursantkami i żeńskim personelem szkoły były ogólnie znane nie tylko personelowi szkoły ale także większej części słuchaczy i na ten temat

36 Wyższa kadra CS MBP faktycznie miała eleganckie mieszkania w kamienicy przy ul. Piramowicza 15. Według zapisów w książce telefonicznej z połowy $1945 \mathrm{r}$. zamieszkiwali tam np. mjr L. Ajzen (były dowódca Szkoły Oficerów Bezpieczeństwa Publicznego w Lublinie), mjr M. Broniatowski (aktualny dowódca CS), por. T. Bierzwicki (zastępca dowódcy) i por. dr Emil Merz (kierownik Wydziału Szkoleniowego CS). Por. Spis Abonentów Sieci Telefonicznej Dyrekcji Okręgu Poczt i Telegrafów w Łodzi na 1945 r., Łódź 1945, passim.

37 Do ob[ywatela] Ministra Bezpieczeństwa Publicznego gen. bryg. Radkiewicza, 5 V 1947 r., AIPN Wa, 0194/1763, k. 50; Do wiceministra Bezpieczeństwa Publicznego płk. Mietkowskiego, 25 I 1946 r., ibidem, k. 47. Szerzej o osobie mjr./płk. M. Broniatowskiego: K. Lesiakowski, Mieczysław Broniatowski-meandry kariery „dąbrowszczaka” w PRL, „Przegląd Nauk Historycznych” 2015, R. XIV, nr 1, s. $107-131$.

38 Życiorys, 25 III 1948 r., AIPN Wa, 698/224 t. 1, k. 12-13; Ankieta specjalna, brak daty, ibidem, k. 14. 
bardzo dużo rozmawiano nazywając mjr. "Rasputinem" lub też gdy spotykano przystojna kobietę mówiono: na nią trzeba "Tadzika" (mjr. Bierzwińskiego)"39. W tej sytuacji za całkowicie bałamutna należy uznać opinię jego bezpośredniego przełożonego, który pewnie ratując przy okazji swoja pozycję, w marcu 1947 r. wystawił mjr. T. Bierzwińskiemu bardzo pozytywną opinię: „Na stanowisku $z$ [astępc]y d[owódc]y Szkoły pracuje b[ardzo] dobrze, $z$ głębokim zrozumieniem zadań wychowawczych i administratora. [...] Człowiek o wysokim poziomie moralnym [...]"40. Można dodać, że po usunięciu wspomnianego oficera ze szkoły $z$ dniem 1 października 1947 r. i powierzeniu mu w 1948 r. stanowiska zastępcy szefa Biura Rejestracji Cudzoziemców w Komendzie Głównej MO dalej postępował on w podobny sposób i tylko $z$ uwagi na „rewolucyjna przeszłość" unikał poważniejszych konsekwencji.

Trzecią osobą ze ścisłego kierownictwa placówki był por./kpt. dr Emil (właściwie Samuel) Merz (ur. w 1894 r.). Przed wybuchem wojny był komunizującym adwokatem w Warszawie (ukończył prawo na Uniwersytecie w Wiedniu). W latach 1939-1941 we Lwowie był pracownikiem sowieckiej propagandy i cenzorem, po ewakuacji w głab ZSRR pracował w zakładach metalurgicznych w Donbasie, a następnie w kołchozie w Kirgizji. Od maja 1943 r. był w nowym WP m.in. w szkole oficerów politycznych w Riazaniu ${ }^{41}$. Od października 1944 r. w Resorcie Bezpieczeństwa, później MBP, dokładniej w Wydziale Obozów. Z dniem 3 stycznia 1945 r. został przeniesiony do Szkoły Oficerów BP na stanowisko zastępcy kierownika do spraw wyszkolenia. W lipcu tego samego roku został kierownikiem Wydziału Szkoleniowego w CS, a od stycznia roku następnego przeszedł do centrali MBP na stanowisko zastępcy kierownika Wydziału Szkoleniowego, w kwietniu zaś naczelnika Wydziału Szkoleniowego Zarządu Personalnego ministerstwa ${ }^{42}$. To oznacza, że od tego momentu w jego kompetencjach był nadzór nad CS w Łodzi. Był dobrze oceniany za pracę w dziedzinie szkolenia kadr dla bezpieki („z obowiązków swych wywiąuje się dobrze. Pracę tę lubi i w zupełności jej odpowiada"43). Po problemach ze zdrowiem i brakiem porozumienia

${ }^{39}$ Raport $\mathrm{z}$ wyników dochodzenia p[rzeciw]ko Z[astęp]cy Dyrektora Centrum Wyszkolenia MBP mjr. Bierzwińskiemu, 14 I 1948 r., AIPN Wa, 698/224 t. 1, k. 64.

${ }^{40}$ Charakterystyka, 14 III 1947 r., AIPN Wa, 698/224 t. 1, k. 69.

41 Życiorys, 17 X 1944 r., AIPN Wa, 0193/3292, k. 5-5v.

${ }^{42}$ Do rozkazu, 17 I 1946 r., AIPN Wa, 0193/3292, k. 17; Charakterystyka E. Merza, 3 IV 1946 r., ibidem, k. 17.

${ }^{43}$ Charakterystyka E. Merza, 3 IV 1946 r., AIPN Wa, 0193/3292, k. 19. 
z przełożonymi w MBP w połowie 1948 r. przeszedł do Ministerstwa Obrony Narodowej. W ten sposób otwierała się przed nim kariera w komunistycznym sądownictwie wojskowym. Przewodniczył m.in. sekcji tajnej Sąu Najwyższego, która 20 października 1952 r. podtrzymała wyrok skazujący na śmierć gen. Emila Fieldorfa ps. „Nil”, byłego szefa Kedywu.

\section{„Kujbyszewiacy”}

Trzon kadry, która wykładała przedmioty specjalne, stanowili tzw. kujbyszewiacy, czyli absolwenci słynnego kursu specjalnego NKWD w Kujbyszewie $z$ pierwszej połowy 1944 r. Wiodąca rolę odgrywał ppor./kpt. Antoni Tomnicki, wykładowca szkoły w Lublinie i faktyczny organizator szkolenia specjalnego w Łodzi. Jego zasługą było m.in. przygotowanie podstawowych konspektów zajęć ${ }^{44}$. Po przejściu kpt. E. Merza do Warszawy objał zwolnione stanowisko zastępcy dyrektora placówki do spraw szkoleniowych.

Drugim co do ważności „kujbyszewiakiem” po kpt. A. Tomnickim był por. Wiktor Łoj. Urodzony w czerwcu 1919 r. w Krasnojarskim Kraju w Związku Sowieckim, w jednej $z$ ankiet napisał, że nie może podać dokładnej daty dziennej swojego przyjścia na świat, „gdyż metryki zniszczono w czasie wojny domowej w Rosji" ${ }^{45}$. Miał też problem $z$ określeniem swojego obywatelstwa, ale narodowość podawał polska. Od marca 1946 r. pełnił funkcję kierownika Wydziału Szkolenia w CS. Miał kwalifikacje pedagogiczne, jako przedwojenny sowiecki nauczyciel był dobrze oceniany przez przełożonych, choć czasem pojawiały się zarzuty nadmiernej tolerancji wobec kursantów $^{46}$. W drugiej połowie 1947 r. odgrywał bardzo dużą rolę w Centrum Wyszkolenia MBP w Legionowie, jednak $z$ czasem pogubił się na płaszczyźnie obyczajowej. W efekcie jako sowiecki oficer w 1954 r. powrócił do ZSRR.

Inny „kujbyszewiak” to por. Konstanty Jankowski - dowódca batalionu i wykładowca. Ten niespełna trzydziestoletni pracownik CS (ur. w 1918 r.) przez przełożonych był oceniany jako osoba mało pracowita i obowiązkowa oraz tzw. średniej pewności politycznej. Trochę zaskakuje ta opinia, gdy weźmie się pod uwagę, że w szkole został dowódcą batalionu. Pamiętać też trzeba, że w trakcie kursu

${ }^{44}$ Sprawozdanie z pracy Szkoły Ministerstwa Bezpieczeństwa Publicznego za okres 3 lat od grudnia 1944 do grudnia 1947 r., 9 XI 1947 r., AIPN Wa, 1572/234, k. 28.

${ }^{45}$ Ankieta specjalna, brak daty, AIPN Wa 0329/81/3, k. 30.

${ }^{46}$ Charakterystyka, 5 IV 1947 r., AIPN Wa 0329/81/3, k. 74. 
w Kujbyszewie musiał się czymś wyróżnić, skoro był dowódca jednej $z$ dwóch kompanii ${ }^{47}$.

„Kujbyszewiakami” byli także por. Józef Łobatiuk ${ }^{48}$, por. Paweł Gobiecki ${ }^{49}$ i por. Ignacy Szarnas - trzech innych wykładowców przedmiotów specjalnych. Ten ostatni (ur. w 1923 r. w Leningradzie), choć deklarował polską narodowość, w 1961 r. zrzekł się obywatelstwa polskiego i najprawdopodobniej wyjechał do Związku Sowieckiego ${ }^{50}$.

Zsowietyzowanym Polakiem, obywatelem ZSRR, a także „kujbyszewiakiem", który został przeniesiony do CS z WUBP Warszawa na początku maja 1945 r., był por. Wiktor Kamieniecki (ur. w 1923 r.). Do Łodzi trafił raczej za karę $z$ powodu pijaństwa i utrzymywania kontaktów $z$ „przypadkową kobieta”. Jego przełożony w opinii napisał jednoznacznie, że „nie powinien on pracować w organach bezpieczeństwa" ${ }^{\prime 1}$. Mimo to został skierowany do szkoły na stanowisko pomocnika wykładowcy (tzw. wykładowca seminaryjny), następnie był wykładowca przedmiotów specjalnych. W tej roli był pozytywnie oceniany przez zwierzchnika z CS. W opinii ze stycznia $1947 \mathrm{r}$. dyrektor ppłk. M. Broniatowski napisał, że kpt. W. Kamieniecki „rokuje wielkie nadzieje na przyszłość”52. Najwyraźniej jednak nie odpowiadała mu praca w polskiej bezpiece i kilkakrotnie składał prośby o umożliwienie mu wyjazdu $z$ do ZSRR. Uzasadniał tę decyzję względami rodzinnymi i wolą dokończenia studiów medycznych. W efekcie na początku 1947 r. uzyskał stosowną zgodę.

Szkoła, jak inne placówki bezpieki, miała także sowieckiego doradcę. W tej roli występował mjr Józef Narkiewicz. Wspomniany

47 Charakterystyka, 5 IV 1947 r., AIPN Wa, 0194/770, k. 60-61; H. Lewandowski, Cele i zadania WSO MSW im. F. Dzierżyńskiego $w$ procesie kształcenia kadr Służby Bezpieczeństwa, „Problemy Teorii i Praktyki Operacyjnej Służby Bezpieczeństwa” 1987, nr 1, s. 51.

48 Rok pierwszy. Powstanie i działalność aparatu bezpieczeństwa publicznego na Rzeszowszczyźnie (sierpień 1944 - lipiec 1945), oprac. D. Iwaneczko, Z. Nawrocki, Rzeszów 2005, s. 52.

49 Urodzony w 1919 r. w Łomży, z zawodu murarz, ukończył siedem klas szkoły powszechnej (Karta ewidencyjna współpracownika Ministerstwa Bezpieczeństwa Publicznego, AIPN Łódź, BU Łd 55110/61-13, bp; Ankieta specjalna, brak daty, AIPN Wa, 0193/486, k. 11).

50 Zeszyt ewidencyjny, brak daty, AIPN Wa, 2154/9, k. 8.

${ }^{51}$ Charakterystyka ppor. Kamienieckiego Wiktora, 27 IV 1945 r., AIPN Wa, 0193/552, k. 30 .

${ }^{52}$ Charakterystyka kpt. Kamienieckiego Wiktora, wykładowcy CS MBP, 30 I 1947 r., AIPN Wa, 0193/552, k. 40. 
oficer był $z$ pochodzenia Polakiem, ale całe swoje życie spędził w ZSRR. Przed wybuchem wojny sowiecko-niemieckiej był dyrektorem szkoły (technikum) w mieście Obajań na południe od Kurska, później - zastępca dowódcy batalionu sowieckiego wojska. W maju 1944 r. został skierowany do Polskiego Sztabu Partyzanckiego. Według niektórych danych jego rola w CS była dodatkowo spotęgowana przez to, że od kwietnia do końca lipca 1945 r. pełnił on funkcję zastępcy dowódcy szkoły. Jednak $z$ uwagi na stan zdrowia od 1 sierpnia był urlopowany, po czym miał być przekazany do dyspozycji Głównego Zarządu Politycznego Armii Czerwonej53.

Obok mniej lub bardzie zrusyfikowanych Polaków w CS zatrudniano także co najmniej jednego oficera sowieckiego narodowości rosyjskiej. Chodzi tu o lekarza szkoły, por. Antoninę Naumowa. Wspomniana lekarka (ur. w 1920 r.) trafiła do szkoły w Lublinie, przydzielona przez Szefostwo Służby Sanitarnej WP. Gdy z dniem 1 sierpnia 1946 r. w stopniu kapitana odchodziła na własna prośbę w związku $z$ wyjazdem do ZSRR, w konkluzji jej charakterystyki pojawiła się wielce wymowna fraza: „Obywatel sowiecki, godnie reprezentujący swój naród. Pracownik bardzo sumienny" ${ }^{4}$. Wszystko wskazuje na to, że faktycznie przyczyniła się utrzymania poprawnego stanu zdrowotności kursantów, w niewątpliwie niełatwych pod tym względem powojennych realiach.

Pozostali pracownicy szkoły niczym specjalnym się nie wyróżniali, tak jak osoby już wymienione cechował ich młody wiek ${ }^{55}$, tzw. właściwe (zwykle robotnicze) pochodzenie społeczne, niskie wykształcenie i brak odpowiednich kwalifikacji zawodowych. W przyszłości nie zrobili karier w szkolnictwie resortowym, nie mówiąc o innych pionach bezpieki. Oczywiście można jednak wskazać wyjątki od tej reguły. $Z$ pewnościa trzeba tu wymienić ppor. Benedykta Korczewskiego (właściwie Benzion Kerzner, ur. w 1912 r.). Zanim został kierownikiem, następnie naczelnikiem Wydziału Finansowo-Gospodarczego CS, pracował na podobnym stanowisku w szkole w Lublinie. Ten przedwojenny działacz komunistyczny, aktywny na wschodnich Kresach Rzeczypospolitej, $z$ tego powodu trzykrotnie

${ }^{53}$ Ankieta specjalna, 13 III 1945 r., AIPN Wa, 0193/736, k. 8; Wniosek, 31 VII 1945 r., ibidem, k. 9; Rozkaz specjalny, 7 VIII 1945 r., ibidem, k. 10.

${ }^{54}$ Charakterystyka kpt. Naumowej Antoniny [czerwiec 1947 r.], AIPN Wa, 0193/738, k. 16.

55 Jedna $z$ telefonistek zatrudnionych w CS w 1945 r. miała tylko 16 lat (Wywiad w sprawie Boruty Krystyny, 4 III 1950 r., AIPN, Wa, 0193/5372, k. 62). 
aresztowany, w 1938 r. wyjechał na stałe z żoną do Persji, gdzie małżonka miała bliska rodzinę. On pracował fizycznie, ale żona - wszystko na to wskazuje - pracowała na niwie wywiadowczej na rzecz konsulatu sowieckiego w Teheranie. Po nawiąaniu kontaktów ze Związkiem Patriotów Polskich B. Korczewski wrócił do Polski w listopadzie 1944 r., a jego żona rok później. Dnia 1 sierpnia 1946 r. przeniesiono go do Warszawy, gdzie objął funkcję kierownika „Budownictwa Szkoły MBP w Legionowie”. W 1947 r. nastapił przełom w jego karierze - związał się Departamentem VII (wywiad), w roku następnym wyjechał na placówkę dyplomatyczną do Izraela, później prowadził działalność wywiadowcza w Berlinie ${ }^{56}$. Zatem dla niego łódzki epizod był dopiero wstępem do szerszej działalności ${ }^{57}$.

\section{Ocena kadry CS MBP}

$Z$ powyższych informacji wynika, że podstawową siłę fachową kadry CS MBP stanowili absolwenci kursu specjalnego w Kujbyszewie. Bez tych zsowietyzowanych Polaków lub wręcz sowieckich obywateli trudno sobie wyobrazić szkolenie pracowników dla bezpieki w Polsce. $Z$ cała pewnościa przenosili oni na polski grunt sowieckie wzory organizacji i prowadzenia pracy operacyjnej. W rzeczywistości były to jednak osoby bardzo młode i w konsekwencji bez większego doświadczenia operacyjnego. O ich niskiej przydatności świadczy i to, że wspomniani „kujbyszewiacy” w przyszłości nie będa odgrywali większej roli w aparacie bezpieczeństwa w Polsce, a niektórzy wyjada $z$ kraju i wróca do ZSRR. Natomiast polscy komuniści $z$ przedwojennym stażem, którzy współtworzyli kadrę szkoły - mjr/ppłk M. Broniatowski i kpt/mjr T. Bierzwiński, choć formalnie zajmowali ważne stanowiska (dyrektora i zastępcy dyrektora placówki), to jednak ich rola w szkoleniu nie wykraczała poza blok zajęć o charakterze polityczno-agitacyjnym i kwestie organizacyjno-gospodarcze. Wynikało to $z$ tego, że nie dysponowali żadnymi innymi kwalifikacjami czy talentami.

56 Życiorys, 19 XI 1944 r., AIPN Łd, 01737/79, k. 5-8; Do Dyrektora CS MBP ppłk. Broniatowskiego, 30 VII 1946 r., ibidem, k. 45; Do Z[astęp]cy Przewodniczacego Komitetu ds. B[ezpieczeństwa] P[ublicznego] płk. Sienkiewicza, 5 VIII 1955 r., ibidem, k. 106.

${ }^{57}$ Trudno $\mathrm{w}$ świetle przedstawionych informacji zgodzić się $z$ opinią, że ppor. B. Korczewski trafił do CS z WUBP Łódź, gdzie rzekomo do końca lipca 1946 r. był naczelnikiem Wydziału Gospodarczego (Aparat bezpieczeństwa $w$ Polsce. Kadra..., s. 298). 
W założeniu CS miała być ważnym narzędziem sowietyzacji Polski, ale w całości nie spełniła pokładanych w niej nadziei. Jedna $z$ przyczyn tego stanu była słabość kadry, ale również umiejscowienie szkoły poza centrum bezpieki, którym była warszawska centrala MBP. W tej sytuacji nie może zaskakiwać to, że wykładowcy CS w Łodzi nie mogli się pochwalić specjalnymi osiągnięciami. Ich niskie kwalifikacje, brak kontaktu $z$ bieżąca praca operacyjną, a także umiejętności przekazywania wiedzy musiały skutkować stosowaniem formalnych metod nauczania i tzw. sierżanckich chwytów. Oczywiście w oficjalnych sprawozdaniach tego rodzaju problemów specjalnie nie eksponowano. Przykładowo kpt. T. Bierzwiński w dokumencie z marca 1946 r., podsumowującym pierwszy rok działalności CS, napisał, że tak wojskowi, jak i cywilni pracownicy „nie tylko formalnie wypełniali swoje obowiazki, [czyli] odwalali swą pracę, ale usiłowali stać się przyjaciółmi, opiekunami słuchaczy"58. Ale w tym samym sprawozdaniu odnotowano także to, że niektórzy wykładowcy w szkoleniu sięgali po metody koszarowe, „doprowadzajac niekiedy do obniżenia godności słuchacza, godności pracownika bezpieczeństwa"59. Skutkiem tego niektórych pracowników trzeba było zwolnić, zwłaszcza dotyczyło to nowo zatrudnionych osób, wybranych spośród absolwentów pierwszego kursu zakończonego w czerwcu 1945 r.

Ponadto należy wspomnieć, że w CS zanotowano przypadki zwolnień pracowników $z$ powodu aresztowania, „pijaństwa i wrogiego stosunku do ustroju" czy złożenia w czasie wojny podpisu na podaniu o wpisanie na tzw. volkslistę ${ }^{60}$. Skutkiem tego był spory ruch kadrowy. Głównie jednak był on zdominowany przez rozmaite przeniesienia, przeszeregowania i awanse oraz odejścia na własna prośbę, a nie przez odwołania $z$ powodów politycznych. Incydentalnie zdarzały się też dezercje oraz zgony w wyniku postrzału (brak danych o okolicznościach tego rodzaju wypadków) ${ }^{61}$.

58 Sprawozdanie $z$ rocznej pracy CS MBP, wygłoszone dnia 31 III 1946 r. na uroczystości Szkoły przez kpt. Bierzwińskiego, 8 IV 1946 r., AIPN Wa, 1572/234, k. 20.

59 Ibidem.

${ }^{60}$ Chodzi o Niemiecką Listę Narodową (Deutsche Volksliste).

61 Wyciag z rozkazu personalnego nr 204, 20 VI 1946 r., AIPN Wa, 1509/7296, k. 93; Wyciag z rozkazu personalnego nr 212, 7 VII 1946 r., ibidem, k. 96; Wyciag z rozkazu personalnego $\mathrm{nr}$ 331, 18 VIII 1946 r., ibidem, k. 106; Wyciag z rozkazu personalnego nr 343, 25 VIII 1945 r., ibidem, k. 107; Wyciag z rozkazu personalnego nr 467, 25 X 1946 r., ibidem, k. 123. 
Podsumowujacc, należy stwierdzić, że przed CS MBP postawiono bardzo ważne zadanie. W jej murach miały się przygotowywać zastępy mocno rozbudowywanej po 1944 r. polskiej bezpieki. Najlepsi absolwenci szkoły byli przewidywani m.in. na stanowiska kierownicze $\mathrm{w}$ powiatowych urzędach bezpieczeństwa publicznego. Zespół z ppłk. M. Broniatowskim na czele, choć wzmocniony zastępem absolwentów specjalnego kursu NKWD w Kujbyszewie, $z$ uwagi na swoją mała liczebność i słabość fachową nie miał w zasadzie możliwości, aby podołać temu wyzwaniu. W efekcie CS nie stała się „kuźnią kadr polskiej bezpieki”, lecz rodzajem kursu przygotowawczego dla ok. 2,4 tys. funkcjonariuszy, bo tyle osób przeszkolono podczas jej funkcjonowania w Łodzi do sierpnia $1947 \mathrm{r}$.

\section{Bibliografia}

\section{$\dot{Z}_{\text {RÓdea ARCHIWALNE }}$}

Archiwum Instytutu Pamięci Narodowej w Warszawie

0193/486, 0193/552, 0193/736, 0193/738, 0193/3292, 0193/5372, 0194/1763, 0194/770, 0218/2045, 0329/81/3, 698/224 t. 1, 1509/7296, 1510/52, 1572/234, 1572/257, 2154/9, MBP 2133, MBP 2279, MBP 2739.

Archiwum Instytutu Pamięci Narodowej Oddział w Łodzi

BU Łd 55110/61-13, 01737/79, 748/61/18.

\section{WYDAWNICTWA ŻRÓDEOWE}

Kształtowanie władzy ludowej w Łodzi i województwie Łódzkim w 1945 roku. Wybór źródeł, oprac. G. Adamczewska, M. Bandurka, E. Chobot, WarszawaŁódź 1985.

Rok pierwszy. Powstanie i działalność aparatu bezpieczeństwa publicznego na Rzeszowszczyźnie (sierpień 1944 - lipiec 1945), oprac. D. Iwaneczko, Z. Nawrocki, Rzeszów 2005.

\section{INFORMATORY}

Aparat bezpieczeństwa w Polsce. Kadra kierownicza, t. I (1944-1956), red. K. Szwagrzyk, Warszawa 2005.

Kochański A., Polska 1944-1991. Informator historyczny, t. I (Podział administracyjny. Ważniejsze akty prawne, decyzje i enuncjacje państwowe [1944-1956]), Warszawa 1996.

Spis Abonentów Sieci Telefonicznej Dyrekcji Okręgu Poczt i Telegrafów w Łodzi na 1945 r., Łódź 1945. 


\section{Opracowania}

Archiwalia komunistycznego aparatu represji: zagadnienia źródłoznawcze, red. F. Musiał, Kraków 2012.

Bakalarczyk A., Zapiski kursanta Centralnej Szkoły MBP w Łodzi, [w:] Legionowski ośrodek szkolenia Służby Bezpieczeństwa, cz. 1 (Kujbyszew-Lublin-Łódź), Legionowo 1989.

Broniatowski M., Organizacja wojewódzkich urzędów bezpieczeństwa publicznego w Rzeszowie i Warszawie (sierpień 1944 - styczeń 1945), „Zeszyty Historyczne Akademii Spraw Wewnętrznych" 1986, t. VI.

Cichocki B., Jóźwiak K., Najważniejsze są kadry. Centralna Szkoła Partyjna PPR/ PZPR, Warszawa 2006.

Ciupa R., Komaniecka M., Szpiegowski arsenał bezpieki: obserwacja, technika operacyjna, kontrola korespondencji jako środki pracy Służby Bezpieczeństwa $P R L$, Katowice 2011.

Fraczek A., Wspomnienia absolwenta, [w:] Legionowski ośrodek szkolenia Służby Bezpieczeństwa, cz. 1 (Kujbyszew-Lublin-Łódź), Legionowo 1989.

Historyczno-prawna analiza struktur organów bezpieczeństwa Polski Ludowej (1944-1990): zbiór studiów, red. A. Jusupović, R. Leśkiewicz, Warszawa 2013.

Jaworski M., Korpus Bezpieczeństwa Wewnętrznego 1945-1965, Warszawa 1984.

Korkuć M., „Kujbyszewiacy” - awangarda UB, „Arcana” 2002, z. 46-47.

Krasucki E., Międzynarodowy komunista. Jerzy Borejsza - biografia polityczna, Warszawa 2009.

Lesiakowski K., Mieczysław Broniatowski - meandry kariery "dąbrowszczaka” w PRL, „Przegląd Nauk Historycznych” 2015, R. XIV, nr 1.

Lewandowski H., Cele i zadania WSO MSW im. F. Dzierżyńskiego w procesie ksztatcenia kadr Stużby Bezpieczeństwa, „Problemy Teorii i Praktyki Operacyjnej Służby Bezpieczeństwa” 1987, nr 1.

Ochrona bezpieczeństwa państwa i porzadku publicznego w Polsce 1944-1988, red. T. Walichnowski, Warszawa 1989.

Polegli $w$ walce o władze ludowa. Materiały i zestawienia statystyczne, oprac. B. Brzeziński, L. Chrzanowski, Warszawa 1970.

Skwarczek L., Wspomnienia z łódzkiego okresu Centralnej Szkoły Ministerstwa Bezpieczeństwa Publicznego, [w:] Legionowski ośrodek szkolenia Stużby Bezpieczeństwa, cz. 1 (Kujbyszew-Lublin-Łódź), Legionowo 1989.

Ślęczka J., Rodowód Wyższej Szkoły Oficerskiej im. F. Dzierżyńskiego, Warszawa 1989.

Terlecki R., Miecz i tarcza komunizmu: historia aparatu bezpieczeństwa $w$ Polsce 1944 1990, Kraków 2013.

Wokół teczek bezpieki: zagadnienia metodologiczno-źródłoznawcze, red. F. Musiał, Kraków 2006.

W służbie ludowej ojczyzny i społeczeństwa. Wobronie ładu i porządku społecznego, red. Z. Jakubowski, Łódź 1986. 
Wybór wydarzeń $z$ dziejów walk $w$ obronie władzy ludowej $w$ Polsce $w$ latach 1944 1952, red. T. Walichnowski, Warszawa 1985.

Wyższa Szkoła Oficerska MSW im. F. Dzierżyńskiego. Rodowód, powstanie i działalność, Warszawa 1983.

„Zwyczajny resort”. Studia o aparacie bezpieczeństwa 1944-1956, red. K. Krajewski, T. Łabuszewski, Warszawa 2005.

\section{The staff od the Central School of the Ministry of Public Security 1945-1947. The origins of the Polish security service}

S ecurity apparatus was a very important vehicle which was used by communists $\checkmark$ during the fight for power after II World War. Thousands of functionaries needed the appropriate schooling. During 1945-1947 they were trained by Central School of Ministry of Public Security in Łódź. The lecturers in this School were the prewar Polish communists and so-called „kujbyszewiacy” - the graduates from NKVD [People's Commissariat for Internal Affairs] - a course which was organized in the period between April-July 1944 in the Soviet town Kuybyshev on the river Volga. The personnel was characterized by young age and lack of professional experience. Therefore their usefulness for education of functionaries of security apparatus in the postwar Poland was minore.

Keywords: security apparatus in Poland, Ministry of Public Security, training center of functionaries, Central School of Ministry of Public Security 1945-1947. 